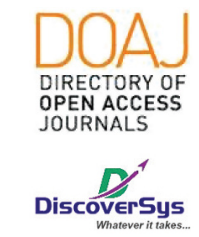

Published by DiscoverSys

\title{
Faktor-faktor yang mempengaruhi kualitas hidup pasien kanker tiroid berdiferensiasi baik (DTC) paska tiroidektomi total di Rumah Sakit Umum Pusat (RSUP) Sanglah, Denpasar
}

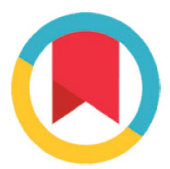

CrossMark

\author{
I Gusti Ngurah Gde Dwi Aryanata ${ }^{1 *}$, I Wayan Sudarsa², \\ Putu Anda Tusta Adiputra ${ }^{2}$
}

\section{ABSTRACT}

Background: Thyroid Cancer is the most common endocrine cancer. The majority of thyroid cancer (80-85\%) is well differentiated. Surgery is the treatment of choice for Well-Differentiated Thyroid Cancer (DTC). This research aims to evaluate the quality of life of patients with thyroid cancer who have undergone total thyroidectomy compared to the general population and also assess the influencing factors.

Methods: This research includes 50 patients suffering from DTC after total thyroidectomy and 50 participants were selected to represent the general population who are then asked to fill out a detailed questionnaire EORTC QLQ 30 Indonesia Version including demographic data and clinical data as the TSH levels, the type of histopathology and interval of time since diagnosis, taken from the patient's medical record. Data were analyzed using independent t-test and linear regression in STATA 14 for windows.

Results: It is evident that the quality of life of patients with DTC after total thyroidectomy is significantly lower compared to the general population $(\mathrm{P}<0.05)$. In addition, several factors such as age, educational level and income of the family give a strong influence as for gender, marital status, employment status, and the time interval since diagnosis gives a mild influence to the quality of life $(P<0.05)$. However, TSH levels and type of histopathology was not proven to affect the quality of life ( $P>0.05$ )

Conclusion: There are several factors related to quality of life among patients with DTC such as age, educational level and income of the family, gender, marital status, employment status, and the time interval since diagnosis
1Program Studi Ilmu Bedah, Fakultas Kedokteran, Universitas Udayana, Bali, Indonesia ${ }^{2}$ Subdivisi Bedah Onkologi, Departemen IImu Bedah, Fakultas Kedokteran, Universitas Udayana, Bali, Indonesia

* Corresponding:

I Gusti Ngurah Gde Dwi Aryanata; Program Studi llmu Bedah, Fakultas Kedokteran, Universitas Udayana, Bali, Indonesia; voodoodolldjelantik@gmail.com

Diterima : 30-11-2018

Disetujui : 29-03-2019

Diterbitkan : 01-04-2019
Keywords: quality of life, thyroid cancer, DTC

Cite This Article: Aryanata, I.G.N.G.D., Sudarsa, I.W., Adiputra, P.A.T. 2019. Faktor-faktor yang mempengaruhi kualitas hidup pasien kanker tiroid berdiferensiasi baik (DTC) paska tiroidektomi total di Rumah Sakit Umum Pusat (RSUP) Sanglah, Denpasar. Intisari Sains Medis 10 (1): 197-204. D0I: 10.1556/ism.v10i1.379

\section{ABSTRAK}

Latar belakang: Kanker tiroid merupakan kanker endokrin yang paling sering ditemukan. Sebagian besar kanker tiroid (80-85\%) berdifferensiasi baik (DTC). Pembedahan merupakan pengobatan pilihan pada DTC. Penelitian ini bertujuan untuk mengetahui kualitas hidup pasien dengan kanker tiroid khususnya yang telah menjalani tiroidektomi total dibandingkan dengan populasi umum dan juga mengevaluasi faktor mempengaruhnya.

Metode: Penelitian ini meliputi 50 pasien yang menderita DTC paska total tiroidektomi dan 50 peserta yang dipilih untuk mewakili populasi umum yang kemudian diminta mengisi kuisioner EORTC QLQ 30 Versi Indonesia beserta data demografi dan data klinis seperti kadar TSH, jenis histopatologi dan interval waktu sejak diagnosis ditegakkan, diambil dari rekam medik pasien. Analisa data mengunakan Independent T-test dan Regresi Linear dilakukan pada program STATA 14.

Hasil: Terbukti bahwa kualitas hidup pasien DTC paska tiroidektomi total lebih rendah dibandingkan dengan populasi umum $(P<0.05)$. Beberapa faktor seperti usia, tingkat pendidikan dan penghasilan keluarga memberikan pengaruh kuat sedangkan jenis kelamin, status pernikahan, status pekerjaan, dan interval waktu sejak diagnosis memberikan pengaruh ringan terhadap kualitas hidup $(\mathrm{P}<0.05)$. Akan tetapi, faktor kadar TSH dan jenis histopatologi tidak terbukti mempengaruhi kualitas hidup pasien kanker tiroid berdifferensiasi baik (DTC) paska tiroidektomi total $(P>0,05)$

Kesimpulan: Terdapat beberapa faktor yang berhubungan dengan kualitas hidup pasien DTC seperti usia, tingkat pendidikan dan penghasilan keluarga, jenis kelamin, status pernikahan, status pekerjaan, dan interval waktu sejak diagnosis
Kata Kunci: kualitas hidup, kanker tiroid, DTC

Site Pasal Ini: Aryanata, I.G.N.G.D., Sudarsa, I.W., Adiputra, P.A.T. 2019. Faktor-faktor yang mempengaruhi kualitas hidup pasien kanker tiroid berdiferensiasi baik (DTC) paska tiroidektomi total di Rumah Sakit Umum Pusat (RSUP) Sanglah, Denpasar. Intisari Sains Medis 10 (1): 197-204. D0l: 10.1556/ism.v10i1.379 


\section{PENDAHULUAN}

Kanker Tiroid merupakan kanker endokrin yang paling umum dengan insiden sekitar 1.0\%-1,5\% kasus baru setiap tahun di Amerika Serikat dan insidennya terus meningkat dalam tiga dasawarsa terakhir di seluruh dunia. ${ }^{1}$ Menurut data registrasi kanker di Indonesia, kanker tiroid menempati urutan ke-sembilan kanker tersering. Sebagian kanker tiroid (80-85\%) berasal dari sel folikuler yang merupakan kanker tiroid berdifferensiasi baik, sedang sisanya kanker tiroid anaplastik/ berdifferensiasi buruk, karsinoma medullaris berasal dari sel para folikuler dan sel ganas (nontiroid) lainnya. ${ }^{2}$ Berdasarkan penelitian di Rumah Sakit Umum Pusat Sanglah, dari semua kasus kanker tiroid didapatkan kasus kanker tiroid berdifferensiasi baik sebanyak $92.3 \%$ dimana $80 \%$ merupakan kanker tiroid tipe papiler dan 15\% merupakan tipe folikuler. ${ }^{3}$ Nodul tiroid merupakan gejala yang paling umum pada karsinoma tiroid berdifferensiasi baik. Pembedahan merupakan pengobatan pilihan pada karsinoma berdifferensiasi baik. Pada karsinoma tiroid papiler, tiroidektomi total dianjurkan oleh beberapa ahli bedah sebagai pengobatan pilihan. ${ }^{4}$

Petunjuk penatalaksanaan karsinoma tiroid berdifferensiasi baik merekomendasikan tiroidektomi total atau mendekati total (near total) untuk tumor dengan ukuran lebih dari 1 $\mathrm{cm}$, pasien dengan kategori risiko tinggi seperti multifokal, adanya metastasis, riwayat terpapar radiasi, dan riwayat keluarga dengan kanker tiroid. Pilihan ini didasarkan pada pertimbangan bahwa reseksi kelenjar tiroid menyeluruh meningkatkan kelangsungan hidup dan mengurangi angka rekurensi. ${ }^{5}$ Selain itu, kondisi hipotiroidisme setelah operasi tiroidektomi total akan memerlukan penggantian hormon tiroid seumur hidup dimana dapat memicu keadaan hipokalsemia akibat kekurangan hormon tiroid. Semua hal tersebut diatas akan mempengaruhi kualitas hidup pasien paska operasi tiroidektomi total. ${ }^{6}$

Dalam beberapa penelitian mengenai kualitas hidup pasien dengan kanker tiroid didapatkan data yang kontroversial. Pasien menunjukkan penurunan Kualitas Hidup Berkaitan dengan Kesehatan (Health Related Quality of Life/HRQoL) dibandingkan dengan populasi secara umum. Husson et al dalam penelitiannya menyatakan bahwa pasien kanker tiroid secara signifikan dan secara klinis relevan memiliki tingkat Physical dan Psychologicalfunctioninglebih rendah dibandingkan dengan populasi normal dan mengalami lebih banyak keluhan/gejala setelah dibandingkan berdasarkan umur dan jenis kelamin. ${ }^{7}$

Beberapa penulis mengemukakan faktor-faktor yang mempengaruhi kualitas hidup pada pasien dengan kanker tiroid berdifferensiasi baik paska tiroidektomi total antara lain: jenis kelamin lakilaki, usia, tingkat pendidikan, kadar TSH. ${ }^{8}$ Ratki et al., 2016 menyebutkan faktor usia, jenis kelamin, tingkat pendidikan, status pernikahan, penghasilan keluarga, status pekerjaan, tipe histopatologi DTC mempengaruhi kualitas hidup. ${ }^{9}$ Sedangkan Hee dan Smi dalam penelitiannya menambahkan ada komplikasi disfonia, depresi dan fatigue merupakan faktor yang mempengaruhi penurunan kualitas hidup. $^{10}$

Di Rumah Sakit Umum Pusat Sanglah belum pernah dilakukan penelitian mengenai kualitas hidup pasien dengan kanker tiroid dan adanya data yang kontroversial mengenai kualitas hidup pasien dengan kanker tiroid memicu keinginan kami untuk meneliti hal tersebut. Dalam kesempatan ini penulis bermaksud melakukan penelitian untuk mengetahui kualitas hidup pasien dengan kanker tiroid khususnya yang telah menjalani tiroidektomi total dibandingkan dengan populasi umum dan juga mengevaluasi apakah faktor usia, jenis kelamin, tingkat pendidikan, status pernikahan, status pekerjaan, penghasilan keluarga, kadar hormone TSH, interval waktu sejak dilakukan operasi dan jenis histopatologi DTC mempengaruhnya kualitas hidup pasien.

Tujuan utama dari penelitian ini adalah untuk mengetahui kualitas hidup pasien dengan kanker tiroid paska tiroidektomi total dibandingkan dengan populasi umum dan faktor yang mempengaruhinya. Dengan tujuan khusus untuk mengetahui hubungan antara usia, jenis kelamin, tingkat pendidikan, status pernikahan, status pekerjaan, penghasilan keluarga, kadar hormone TSH, interval waktu setelah diagnosis dan jenis histopatologis dengan kualitas hidup pasien kanker tiroid berdifferensiasi baik (DTC) paska tiroidektomi total.

\section{METODE PENELITIAN}

Penelitian ini adalah penelitian observasional analitik dengan rancangan cross-sectional atau potong lintang pada pasien kanker tiroid berdifferensiasi baik (DTC) paska tiroidektomi total di poliklinik Bedah Onkologi Rumah Sakit Umum Pusat Sanglah sejak bulan November 2017-Januari 2018 yang memenuhi kriteria pemilihan sampel dan diambil secara konsekutif (Consucutive sampling).

Kriteria inklusi dalam penelitian ini adalah pasien kanker tiroid berdifferensiasi baik (DTC) paska tiroidektomi total yang kontrol ke Poliklinik Bedah Onkologi RSUP Sanglah. Kriteria eksklusi pada penelitian ini antara lain pasien yang menolak berpartisipasi dalam penelitian, pasien dengan 
kondisi kritis, terdapat disabilitas intelektual, pasien dengan penyakit penyerta lain seperti gangguan mental atau fisik penyakit kronis yang mempengaruhi kesehatan terkait QoL seperti diabetes melitus, penyakit arteri koroner, gagal ginjal kronis, kejang, multiple sclerosis, penyakit rematik, penyakit vaskular serebral, riwayat operasi lain kurang dari 6 bulan, gangguan bipolar manic depresi, depresi, skizofrenia, kecemasan umum berat atau penyakit kronis lainnya.

Variabel tergantung pada penelitian ini adalah kualitas hidup pasien kanker tiroid berdifferensiasi baik (DTC) paska tiroidektomi total yang diukur dengan menggunakan kuisioner EORTC QLQ-C30 Versi Indonesia. Variabel bebas pada penelitian ini adalah usia, jenis kelamin, status ekonomi, tingkat

Tabel 1. Karakteristik Sosiodemografi Pasien Kanker Tiroid dan Populasi Umum.

\begin{tabular}{|c|c|c|c|c|c|}
\hline \multirow[t]{2}{*}{ Parameter } & \multicolumn{2}{|c|}{ Pasien kanker tiroid } & \multicolumn{2}{|c|}{ Populasi umum } & \multirow{2}{*}{ Nilai $p$} \\
\hline & Total & $\%$ & Total & $\%$ & \\
\hline$\overline{\mathrm{N}}$ & 50 & 100 & 50 & 100 & \\
\hline Usia (Rerata \pm SB) & \multicolumn{2}{|c|}{$46 \pm 15,73$} & \multicolumn{2}{|c|}{$30,78 \pm 29,53$} & $<0,001$ \\
\hline \multicolumn{6}{|l|}{ Jenis kelamin } \\
\hline Perempuan & 43 & 86 & 42 & 84 & \multirow{2}{*}{0,779} \\
\hline Laki-laki & 7 & 14 & 8 & 16 & \\
\hline \multicolumn{6}{|l|}{ Tingkat pendidikan } \\
\hline SD & 14 & 28 & 0 & 0 & \multirow{4}{*}{$<0,00$} \\
\hline SMP & 3 & 6 & 0 & 0 & \\
\hline SMA & 20 & 40 & 0 & 0 & \\
\hline Perguruan Tinggi & 13 & 26 & 50 & 100 & \\
\hline \multicolumn{6}{|l|}{ Status pernikaham } \\
\hline Menikah & 45 & 90 & 39 & 78 & \multirow{2}{*}{0,102} \\
\hline Belum Menikah & 5 & 10 & 11 & 22 & \\
\hline \multicolumn{6}{|l|}{ Status Pekerjaan } \\
\hline Bekerja & 22 & 44 & 50 & 100 & \multirow{2}{*}{$<0,001$} \\
\hline Tidak Bekerja & 28 & 56 & 0 & 0 & \\
\hline \multicolumn{6}{|l|}{ Penghasilan keluarga } \\
\hline$<\mathrm{UMR}$ & 15 & 30 & 0 & 0 & \multirow{2}{*}{$<0,001$} \\
\hline$\geq \mathrm{UMR}$ & 35 & 70 & 50 & 100 & \\
\hline \multicolumn{6}{|l|}{ Kadar TSH } \\
\hline$<0,27$ & 8 & 16 & NA & $\mathrm{NA}$ & \multirow{3}{*}{ NA } \\
\hline $0,27-4,20$ & 28 & 56 & NA & NA & \\
\hline$>4,20$ & 14 & 28 & NA & NA & \\
\hline$($ Rerata \pm SB $)$ & \multicolumn{2}{|c|}{$7,80 \pm 16,65$} & & & \\
\hline \multicolumn{6}{|c|}{ Interval waktu sejak Diagnosis } \\
\hline$\leq 12$ bulan & 26 & 52 & NA & NA & \multirow{3}{*}{ NA } \\
\hline$>12$ bulan & 24 & 48 & NA & NA & \\
\hline$($ Rerata \pm SB $)$ & & 46 & & & \\
\hline \multicolumn{6}{|l|}{ Jenis Histopatologi } \\
\hline Papillary & 46 & 92 & NA & NA & \multirow{2}{*}{ NA } \\
\hline Follicular & 4 & 8 & NA & NA & \\
\hline
\end{tabular}

$\mathrm{N}=$ Jumlah sampel, $\mathrm{SB}=$ Simpang baku, UMR=Upah Minimum Regional, $\mathrm{NA}=$ not applicable. pendidikan, kadar TSH, jangka waktu setelah diagnosis dan komplikasi operasi.

Analisis data dibagi menjadi 3 bagian yaitu analisis deskriptif, analisis bivariate dan analisis multivariate. Untuk variabel bebas berskala katagorikal (2 katagori) akan digunakan analisis independent sample $T$ test atau Mann-Whitney U test. Koefisien Korelasi untuk menilai hubungan antar variable adalah Pearson Correlation test ataupun Spearman's Rank Correlation Coefisien. Analisis Multivariate yang dipergunakan adalah Regresi Linear. Data kemudian diolah menggunakan program computer STATA 14. Tingkat kemaknaan (a) ditentukan pada nilai p (probabilitas) $<0,05$.

\section{HASIL PENELITIAN}

Dari 100 sampel, didapatkan pada kelompok pasien kanker tiroid memiliki rerata usia yang lebih tua dibandingkan dengan populasi umum $(46 \pm 15,73$ tahun vs. $30,78 \pm 29,53$ tahun). Pada kedua kelompok sama-sama didapatkan jumlah peserta perempuan jauh lebih banyak dibandingkan laki-laki ( $86 \%$ vs 84\%). Perbedaan bermakna ditemukan pada usia, tingkat pendidikan, dan penghasilan keluarga $(\mathrm{P}<0.05)$. Karakteristik sosiodemografis pasien dapat dilihat pada Tabel 1. Sedangkan hasil analisa independent t-test terdapat pada Tabel 2.

Hubungan antara usia dengan kualitas hidup pasien kanker tiroid berdifferensiasi baik (DTC) paska tiroidektomi total menunjukkan bahwa usia berpengaruh secara negatif terhadap indikator physical functioning $(\beta=-0,24, \mathrm{p}=0,012)$, cognitif functioning $(\beta=-0,55, p<0,001)$ dan global health status $(\beta=-0,53, p<0,001)$. Sedangkan berpengaruh secara positif terhadap indikator dyspnoea $(\beta=0,53, p<0,001)$, Appetite loss $(\beta=0,44, p=0,004)$, constipation $(\beta=0,29, \mathrm{p}=0,017)$ (Tabel 2 )

Studi ini juga menunjukkan bahwa jenis kelamin mempengaruhi 2 dari 15 indikator kualitas hidup yaitu cognitif functioning dan global health statusPada indikator global health status, kelompok kanker tiroid laki-laki memiliki skor 14,95 poin lebih rendah dibandingkan dengan kelompok kanker tiroid perempuan. Sedangkan pada status pernikahan hanya ditemukan bermakna pada emotional functioning (Tabel 2).

Hasil Independent-T test juga menununjukkan tidak terdapat perbedaan bermakna antara kelompok bekerja dan histopatologi terhadap kualitas hidup $(\mathrm{P}>0.05)$, namun terdapat perbedaan pada beberapa parameter UMR dengan kualitas hidup pasien $(\mathrm{P}<0.05)($ Tabel 3$)$.

Analisis regresi linear menunjukkan bahwa tingkat pendidikan mempengaruhi sebagian besar indikator kualitas hidup, kecuali nausea and vomitting, pain, constipation dan diarrhoea. Tingkat 
Tabel 2. Hasil Analisa Independent T-Test Perbandingan antara kelompok kanker tiroid, jenis kelamin, dan status pernikahan terhadap kualitas hidup

\begin{tabular}{|c|c|c|c|c|c|c|c|c|c|}
\hline \multirow[b]{2}{*}{ Variabel } & \multicolumn{2}{|c|}{ Kelompok } & \multirow[b]{2}{*}{ Nilai p } & \multicolumn{2}{|c|}{ Kelompok } & \multirow[b]{2}{*}{ Nilai P } & \multicolumn{2}{|c|}{ Kelompok } & \multirow[b]{2}{*}{ Nilai P } \\
\hline & $\begin{array}{c}\text { Kanker Tiroid } \\
\text { Rerata } \pm \text { SB }\end{array}$ & $\begin{array}{c}\text { Populasi } \\
\text { Umum } \\
\text { Rerata } \pm S B\end{array}$ & & $\begin{array}{c}\text { Laki-laki } \\
\text { Rerata } \pm S B\end{array}$ & $\begin{array}{c}\text { Perempuan } \\
\text { Rerata } \pm S B\end{array}$ & & $\begin{array}{c}\text { Menikah } \\
\text { Rerata } \pm \text { SB }\end{array}$ & $\begin{array}{c}\text { Tidak } \\
\text { Menikah } \\
\text { Rerata } \pm S B\end{array}$ & \\
\hline \multicolumn{10}{|l|}{ Functional Domain } \\
\hline Physical Functioning & $93,07 \pm 10,69$ & $89,47 \pm 12,35$ & 0,122 & $88,57 \pm 14,25$ & $88,57 \pm 14,25$ & 0,234 & $92,30 \pm 11,00$ & $92,30 \pm 11,00$ & 0,138 \\
\hline Emotional Functioning & $90,00 \pm 11,90$ & $95,17 \pm 9,08$ & 0,016 & $83,33 \pm 11,78$ & $83,33 \pm 11,78$ & 0,111 & $88,89 \pm 12,05$ & $88,89 \pm 12,05$ & 0,047 \\
\hline Social Functioning & $96,67 \pm 8,91$ & $96,33 \pm 10,26$ & 0,863 & $95,24 \pm 12,60$ & $95,24 \pm 12,60$ & 0,652 & $96,29 \pm 9,33$ & $96,29 \pm 9,33$ & 0,383 \\
\hline Role Functioning & $97,33 \pm 8,49$ & $95,33 \pm 11,68$ & 0,329 & $95,24 \pm 12,60$ & $95,24 \pm 12,60$ & 0,487 & $97,04 \pm 8,91$ & $97,04 \pm 8,91$ & 0,465 \\
\hline Cognitif Functioning & $88,67 \pm 15,95$ & $91,67 \pm 13,15$ & 0,307 & $73,81 \pm 13,11$ & $73,81 \pm 13,11$ & 0,007 & $87,41 \pm 16,34$ & $87,41 \pm 16,34$ & 0,094 \\
\hline \multicolumn{10}{|l|}{ Symptom Scale } \\
\hline Fatigue & $9,77 \pm 14,99$ & $20,44 \pm 19,49$ & 0,003 & $11,11 \pm 12,83$ & $11,11 \pm 12,83$ & 0,803 & $10,86 \pm 15,44$ & $10,86 \pm 15,44$ & 0,126 \\
\hline Nausea and Vomitting & $1 \pm 5,23$ & $1,67 \pm 6,94$ & 0,589 & $0 \pm 0$ & $0 \pm 0$ & 0,590 & $1,11 \pm 5,50$ & $1,11 \pm 5,50$ & 0,657 \\
\hline Pain & $6,33 \pm 11,11$ & $7 \pm 12,64$ & 0,780 & $11,90 \pm 12,60$ & $11,90 \pm 12,60$ & 0,155 & $7,03 \pm 11,51$ & $7,03 \pm 11,51$ & 0,182 \\
\hline Dyspnoea & $10,67 \pm 17,09$ & $0,66 \pm 4,71$ & $<0,001$ & $19,05 \pm 17,82$ & $19,05 \pm 17,82$ & 0,164 & $11,85 \pm 17,63$ & $11,85 \pm 17,63$ & 0,143 \\
\hline Insomnia & $10 \pm 21,56$ & $7,33 \pm 18,18$ & 0,505 & $9,52 \pm 16,26$ & $9,52 \pm 16,26$ & 0,950 & $11,11 \pm 22,47$ & $11,11 \pm 22,47$ & 0,279 \\
\hline Appetite loss & $8,66 \pm 17,57$ & $2,67 \pm 9,13$ & 0,035 & $19,05 \pm 17,81$ & $19,05 \pm 17,81$ & 0,092 & $9,63 \pm 18,28$ & $9,63 \pm 18,28$ & 0,249 \\
\hline Constipation & $4,67 \pm 13,49$ & $0,66 \pm 4,71$ & 0,050 & $9,52 \pm 16,27$ & $9,52 \pm 16,27$ & 0,309 & $5,19 \pm 14,13$ & $5,19 \pm 14,13$ & 0,420 \\
\hline Diarrhoea & $0,67 \pm 4,71$ & $0 \pm 0$ & 0,319 & $0 \pm 0$ & $0 \pm 0$ & 0,691 & $0,74 \pm 4,96$ & $0,74 \pm 4,96$ & 0,743 \\
\hline Financial Difficulties & $3,33 \pm 12,14$ & $4 \pm 10,94$ & 0,774 & $4,76 \pm 12,59$ & $4,76 \pm 12,59$ & 0,741 & $3,70 \pm 12,76$ & $3,70 \pm 12,76$ & 0,523 \\
\hline Global Health Status & $86,67 \pm 14,67$ & $87,17 \pm 15,99$ & 0,871 & $73,81 \pm 16,27$ & $73,81 \pm 16,27$ & 0,011 & $85,19 \pm 14,75$ & $85,19 \pm 14,75$ & 0,031 \\
\hline
\end{tabular}

Tabel 3. Hasil Analisa Independent T-Test Perbandingan antara status pekerjaan upah minimum regional (UMR), dan tipe histopatologi terhadap kualitas hidup

\begin{tabular}{|c|c|c|c|c|c|c|c|c|c|}
\hline \multirow[b]{2}{*}{ Variabel } & \multicolumn{2}{|c|}{ Kelompok } & \multirow[b]{2}{*}{ Nilai p } & \multicolumn{2}{|c|}{ Kelompok } & \multirow{2}{*}{ Nilai P } & \multicolumn{2}{|c|}{ Kelompok } & \multirow[b]{2}{*}{ Nilai $P$} \\
\hline & $\begin{array}{c}\text { Bekerja } \\
\text { Rerata } \pm S B\end{array}$ & $\begin{array}{c}\text { Tidak Bekerja } \\
\text { Rerata } \pm \text { SB }\end{array}$ & & $\begin{array}{c}<\mathrm{UMR} \\
\text { Rerata } \pm \text { SB }\end{array}$ & $\begin{array}{c}\geq \text { UMR } \\
\text { Rerata } \pm \text { SB }\end{array}$ & & $\begin{array}{c}\text { Folikuler } \\
\text { Rerata } \pm \text { SB }\end{array}$ & $\begin{array}{c}\text { Papiler } \\
\text { Rerata } \pm \text { SB }\end{array}$ & \\
\hline \multicolumn{10}{|l|}{ Functional Domain } \\
\hline Physical Functioning & $94,55 \pm 7,87$ & $94,55 \pm 7,87$ & 0,391 & $86,67 \pm 14,91$ & $86,67 \pm 14,91$ & 0,004 & $93,33 \pm 7,70$ & $93,33 \pm 7,70$ & 0,960 \\
\hline Emotional Functioning & $91,28 \pm 1246$ & $91,28 \pm 1246$ & 0,503 & $84,44 \pm 13,68$ & $84,44 \pm 13,68$ & 0,029 & $89,58 \pm 12,5$ & $89,58 \pm 12,5$ & 0,942 \\
\hline Social Functioning & $98,48 \pm 4,90$ & $98,48 \pm 4,90$ & 0,204 & $93,33 \pm 13,80$ & $93,33 \pm 13,80$ & 0,083 & $100,00 \pm 0$ & $100,00 \pm 0$ & 0,441 \\
\hline Role Functioning & $98,48 \pm 7,10$ & $98,48 \pm 7,10$ & 0,401 & $93,33 \pm 14,90$ & $93,33 \pm 14,90$ & 0,028 & $100,00 \pm 0$ & $100,00 \pm 0$ & 0,518 \\
\hline Cognitif Functioning & $93,18 \pm 12,24$ & $93,18 \pm 12,24$ & 0,076 & $77,78 \pm 19,59$ & $77,78 \pm 19,59$ & 0,001 & $87,5 \pm 15,96$ & $87,5 \pm 15,96$ & 0,881 \\
\hline \multicolumn{10}{|l|}{ Symptom Scale } \\
\hline Fatigue & $10,61 \pm 15,13$ & $10,61 \pm 15,13$ & 0,733 & $14,07 \pm 17,04$ & $14,07 \pm 17,04$ & 0,188 & $8,33 \pm 10,64$ & $8,33 \pm 10,64$ & 0,843 \\
\hline Nausea and Vomitting & $0,76 \pm 3,55$ & $0,76 \pm 3,55$ & 0,774 & $3,33 \pm 9,34$ & $3,33 \pm 9,34$ & 0,037 & $0 \pm 0$ & $0 \pm 0$ & 0,694 \\
\hline Pain & $3,79 \pm 8,81$ & $3,79 \pm 8,81$ & 0,153 & $10 \pm 13,80$ & $10 \pm 13,80$ & 0,037 & $0 \pm 0$ & $0 \pm 0$ & 0,238 \\
\hline Dyspnoea & $6,06 \pm 13,16$ & $6,06 \pm 13,16$ & 0,091 & $24,44 \pm 19,79$ & $24,44 \pm 19,79$ & $<0,001$ & $16,67 \pm 19,25$ & $16,67 \pm 19,25$ & 0,470 \\
\hline Insomnia & $12,12 \pm 24,22$ & $12,12 \pm 24,22$ & 0,543 & $11,11 \pm 20,57$ & $11,11 \pm 20,57$ & 0,814 & $0 \pm 0$ & $0 \pm 0$ & 0,339 \\
\hline Appetite loss & $9,09 \pm 21,04$ & $9,09 \pm 21,04$ & 0,881 & $15,56 \pm 17,21$ & $15,56 \pm 17,21$ & 0,069 & $8,33 \pm 16,67$ & $8,33 \pm 16,67$ & 0,969 \\
\hline Constipation & $0 \pm 0$ & $0 \pm 0$ & 0,028 & $11,11 \pm 20,57$ & $11,11 \pm 20,57$ & 0,025 & $0 \pm 0$ & $0 \pm 0$ & 0,476 \\
\hline Diarrhoea & $1,51 \pm 7,11$ & $1,51 \pm 7,11$ & 0,263 & $0 \pm 0$ & $0 \pm 0$ & 0,518 & $0 \pm 0$ & $0 \pm 0$ & 0,772 \\
\hline Financial Difficulties & $1,51 \pm 7,11$ & $1,51 \pm 7,11$ & 0,353 & $8,88 \pm 19,79$ & $8,88 \pm 19,79$ & 0,033 & $8,33 \pm 16,67$ & $8,33 \pm 16,67$ & 0,396 \\
\hline Global Health Status & $90,15 \pm 12,24$ & $90,15 \pm 12,24$ & 0,138 & $79,44 \pm 17,21$ & $79,44 \pm 17,21$ & 0,021 & $81,25 \pm 14,23$ & $81,25 \pm 14,23$ & 0,447 \\
\hline
\end{tabular}


Tabel 4. Hasil analisa regresi linear mengenai hubungan antara usia, pendidikan, dan kadar TSH dengan kualitas hidup pada pasien kanker tiroid

\begin{tabular}{|c|c|c|c|c|c|c|c|c|c|}
\hline \multirow{2}{*}{ Variabel } & \multicolumn{3}{|c|}{ Koefisien $\beta$} & \multicolumn{3}{|c|}{ IK 95\% } & \multicolumn{3}{|c|}{ Nilai P } \\
\hline & Usia & Pendidikan & TSH & Usia & Pendidikan & TSH & Usia & Pendidikan & TSH \\
\hline \multicolumn{10}{|l|}{ Functional Domain } \\
\hline Physical Functioning & $-0,24$ & 4,40 & 0,09 & $-0,42-(-0,06)$ & $2,04-6,76$ & $-0,92-0,28$ & 0,012 & $<0,001$ & 0,319 \\
\hline Emotional Functioning & $-0,02$ & 5,14 & 0,05 & $-0,42-0,01$ & $2,55-7,73$ & $-0,16-0,25$ & 0,057 & $<0,001$ & 0,659 \\
\hline Social Functioning & $-0,15$ & 2,65 & 0,09 & $-0,31-0,01$ & $0,55-4,75$ & $-0,06-0,24$ & 0,066 & 0,015 & 0,260 \\
\hline Role Functioning & $-0,10$ & 3,08 & 0,07 & $-0,26-(-0,05)$ & $1,15-5,02$ & $-0,08-0,21$ & 0,178 & 0,002 & 0,365 \\
\hline Cognitif Functioning & $-0,55$ & 7,82 & 0,15 & $-0,79-(-0,31)$ & $4,53-11,12$ & $-0,16-0,42$ & $<0,001$ & $<0,001$ & 0,280 \\
\hline \multicolumn{10}{|l|}{ Symptom Scale } \\
\hline Fatigue & 0,25 & $-5,62$ & $-0,14$ & $-0,01-0,52$ & $-9,02-(-2,23)$ & $-0,40-0,12$ & 0,063 & 0,002 & 0,274 \\
\hline Nausea and Vomitting & $-0,02$ & $-0,23$ & $-0,02$ & $-0,12-0,07$ & $-1,54-1,08$ & $-0,11-0,07$ & 0,648 & 0,721 & 0,720 \\
\hline Pain & 0,11 & $-2,33$ & $-0,09$ & $-0,09-0,31$ & $-5,04-0,38$ & $-0,28-0,11$ & 0,274 & 0,090 & 0,372 \\
\hline Dyspnoea & 0,53 & $-6,73$ & $-0,06$ & $0,25-0,80$ & $-10,55-(-2,92)$ & $-0,36-0,23$ & $<0,001$ & 0,001 & 0,666 \\
\hline Insomnia & 0,20 & $-5,90$ & $-0,17$ & $-0,19-0,59$ & $-11,03-(-0,77)$ & $-0,55-0,20$ & 0,310 & 0,025 & 0,351 \\
\hline Appetite loss & 0,44 & $-8,81$ & $-0,10$ & $0,15-0,74$ & $-12,40-(-5,22)$ & $-0,40-0,21$ & 0,004 & $<0,001$ & 0,518 \\
\hline Constipation & 0,29 & $-2,79$ & $-0,08$ & $0,05-0,53$ & $-6,07-0,50$ & $-0,32-0,15$ & 0,017 & 0,095 & 0,470 \\
\hline Diarrhoea & 0,03 & 0,18 & $-0,02$ & $-0,05-0,12$ & $0,99-1,37$ & $-0,10-0,06$ & 0,447 & 0,757 & 0,645 \\
\hline Financial Difficulties & 0,04 & $-3,15$ & $-0,08$ & $-0,19-0,26$ & $-6,06-(-0,24)$ & $-0,29-0,13$ & 0,749 & 0,034 & 0,439 \\
\hline Global Health Status & $-0,53$ & 7,15 & 0,20 & $-0,75-(-0,30)$ & $4,10-10,19$ & $-0,05-0,45$ & $<0,001$ & $<0,001$ & 0,113 \\
\hline
\end{tabular}

Tabel 5. Hasil Analisa Regresi Linear Mengenai Hubungan Antara Interval Waktu Sejak Diagnosis dengan Kualitas Hidup pada Pasien Kanker Tiroid.

\begin{tabular}{lccc}
\hline \multirow{2}{*}{ Variabel } & \multicolumn{3}{c}{ Interval Waktu Sejak Diagnosis } \\
\cline { 2 - 4 } & Koefisien $\boldsymbol{\beta}$ & IK 95\% & Nilai p \\
\hline Functional Domain & & & \\
$\quad$ Physical Functioning & 0,82 & $-0,04-1,68$ & 0,060 \\
Emotional Functioning & 0,34 & $-1,38-1,28$ & 0,493 \\
Social Functioning & 0,493 & $-0,36-1,10$ & 0,316 \\
Role Functioning & 0,37 & $0,05-1,40$ & 0,035 \\
Cognitif Functioning & 0,73 & $-1,38-1,28$ & 0,935 \\
Symptom Scale & & & \\
Fatigue & $-0,94$ & $-0,26-0,28$ & 0,128 \\
Nausea and Vomitting & 0,17 & $-0,26-0,61$ & 0,427 \\
Pain & $-0,41$ & $-1,33-0,50$ & 0,368 \\
Dyspnoea & $-0,61$ & $-2,02-0,80$ & 0,388 \\
Insomnia & $-1,70$ & $-3,43-0,03$ & 0,054 \\
Appetite loss & $-0,06$ & $-1,52-1,40$ & 0,935 \\
Constipation & $-0,24$ & $-1,37-0,88$ & 0,664 \\
Diarrhoea & 0,19 & $-0,20-0,58$ & 0,332 \\
Financial Difficulties & $-0,40$ & $-1,40-0,61$ & 0,429 \\
Global Health Status & 0,72 & $-0,48-1,93$ & 0,233 \\
\hline
\end{tabular}

pendidikan berpengaruh secara positif terhadap semua indikator pada functional domain dan global health status, sedangkan pada symptom scale, tingkat pendidikan berpengaruh secara negatif (Tabel 4). Hasil yang sama juga ditemukan pada kelompok usia namun pada kelompok TSH dan interval waktu diagnosis terhadap kualitas hidup pasien tidak ditemukan perbedaan bermakna $(\mathrm{P}>0,05)$ (Tabel 4 dan Tabel 5).

\section{PEMBAHASAN}

Sebagian besar peserta penelitian ini adalah perempuan, pada kelompok pasien kanker tiroid sebanyak $86 \%$ dan pada kelompok populasi umum sebanyak $84 \%$. Usia termuda pada kelompok pasien kanker tiroid adalah 18 tahun dan tertua 77 tahun dengan rerata usia 46 tahun, sedangkan pada kelompok populasi umum usia termuda 24 tahun dan tertua 43 tahun, dengan rerata usia 30,78 tahun. Sedangkan pada penelitian oleh Singer et al didapatkan peserta penelitian pada kelompok kanker tiroid sebagian besar perempuan $(\mathrm{n}=98$, $81 \%)$ berusia dibawah 50 tahun $(\mathrm{n}=71,59 \%) .{ }^{11}$

Pada penelitian ini didapatkan hampir seluruh pasien kanker tiroid memiliki jenis histopatologi Papillary Thyroid Carcinoma ( $\mathrm{n}=46,92 \%)$. Pada penelitian oleh Ratki et al didapatkan peserta penelitian pada kelompok kanker tiroid sebagian besar tiroid memiliki jenis histopatologi Papillary Thyroid Carcinoma ( $\mathrm{n}=388, \quad 89.54 \%){ }^{9} \quad$ Pada penelitian oleh Singer et al didapatkan peserta penelitian pada kelompok kanker tiroid sebagian besar memiliki jenis histopatologi Papillary Thyroid Carcinoma $(\mathrm{n}=86,71 \%) .{ }^{11}$

Penelitian ini menunjukkan perbedaan signifikan antara kualitas hidup pasien kanker tiroid dengan populasi umum pada 4 dari 15 indikator kualitas hidup yang digunakan, yaitu emotional functioning, fatigue, dyspnoea dan appetite loss. Sedangkan pada penelitian Singer et al didapatkan pasien kanker tiroid secara signifikan mengalami lebih banyak permasalahan pada hampir semua indikator kualitas hidup, kecuali pada 2 indikator 
yaitu diarrhea dan constipation. ${ }^{11}$ Perbedaan paling menonjol didapatkan pada indikator insomnia (perbedaan rerata $(\beta)=-43,7, \mathrm{p}=<0,001$ ), fatigue $(\beta=38,0, p=<0,001)$ dan role functioning $(\beta=29,7$, $\mathrm{p}+<0,001)$.

Parameter kualitas hidup dipengaruhi secara negatif oleh lama pengobatan dan secara bertahap akan membaik dengan perawatan jangka panjang. Hal berbeda dikemukakan oleh Roberts et al yang juga menggunakan EORTC QLQ 30 dimana didapatkan hampir seluruh pasien kanker thyroid dalam penelitiannya memiliki kualitas hidup yang tinggi pada semua indikatornya. ${ }^{12}$ Crevenna et al mengemukakan bahwa vitality, role physical, mental health, role-emotional dan social functioning secara signifikan terganggu selama tahun pertama setelah diagnosis. ${ }^{13}$ Setelah itu, kualitas hidup meningkatkan sejalan dengan waktu sejak diagnosis awal.

Dalam penelitian ini didapatkan bahwa usia berpengaruh secara negatif terhadap indikator physical functioning $(\beta=-0,24, \mathrm{p}=0,012)$, cognitif functioning $(\beta=-0,55, \quad \mathrm{p}<0,001)$ dan global health status $(\mathrm{B}=-0,53, \mathrm{p}<0,001)$. Hal yang sama dikemukakan oleh Lee et al dimana peningkatan umur saat diagnosis $(\beta=-0,27)$ dan jenis kelamin $(\beta=-12,11)$ berpengaruh negative terhadap indikator physical functioning dan peningkatan usia pada saat evaluasi berpengaruh negative terhadap physical functioning dan cognitif functioning, namun berpengaruh positif terhadap emotional functioning. Namun hasil yang berbeda dilaporkan oleh Ratki et al. dengan menggunakan kuisioner EORTC QLQ 30 dimana didapatkan usia lebih tua memiliki kualitas hidup yang lebih baik. ${ }^{9}$

Pada indikator global health status, kelompok kanker tiroid laki-laki memiliki skor 14,95 poin lebih rendah dibandingkan dengan kelompok kanker tiroid perempuan. Hal berbeda dikemukakan oleh Ratki et al dimana jenis kelamin laki-laki menunjukkan skor kualitas hidup yang lebih tinggi dibandingkan dengan perempuan. ${ }^{9}$ Lee et al., 2010 melaporkan bahwa jenis kelamin perempuan mempunyai pengaruh negative terhadap physical functioning $(\beta=-12,11)$ dan juga terhadap emotional functioning $(\beta=-7,47) .{ }^{14}$ Almeida et al., 2009 tidak menemukan adanya hubungan antara jenis kelamin dengan kualitas hidup pasien kanker tiroid. ${ }^{15}$

Penelitian ini juga menunjukkan bahwa tingkat pendidikan mempengaruhi sebagian besar indikator kualitas hidup, kecuali nausea and vomitting, pain, constipation dan diarrhoea. Hasil selaras dilaporkan oleh Ratki et al dimana tingkat pendidikan lebih tinggi berpengaruh terhadap physical functioning $(\mathrm{p}=0.041)$, emotional functioning $(\mathrm{p}=0,040)$, nausea and vomiting $(\mathrm{p}=0,004)$, pain $(\mathrm{p}=0,020)$, financial difficulties $(\mathrm{p}=0,008)$ dan global health status $(\mathrm{p}=0,004) .^{9}$ Demikian juga penelitian oleh Aschebrook-kilfoy et al mengemukakan bahwa semakin tinggi tingkat pendidikan maka nilai kualitas hidup pasien tiroid akan semakin baik. ${ }^{16}$

Pada indikator global health status, kelompok kanker tiroid yang sudah menikah memiliki skor 14,81 poin lebih rendah dibandingkan dengan yang belum menikah. Dalam penelitian oleh Lee et al yang juga menggunakan EORTC QLQ-30, didapatkan bahwa status pernikahan tidak mempengaruhi kualitas hidup pasien kanker tiroid. ${ }^{14}$ Penelitian oleh Ratki et al didapatkan bahwa status penikahan mempengaruhi indikator insomnia dimana pasien yang sudah menikah memiliki gejala insomnia yang lebih rendah dibandingkan yang sudah menikah $(\mathrm{p}=0,028){ }^{9}$

Pada penelitian ini didapatkan bahwa penghasilan keluarga mempengaruhi sebagian besar indikator kualitas hidup pasien kanker tiroid berdifferensiasi baik (DTC) paska tiroidektomi total. Pasien dengan penghasilan keluarga dibawah UMR memiliki skor yang lebih rendah pada semua indikator functional domain dan global health status, sedangkan pada symptom scale, pasien kanker tiroid dengan penghasilan keluarga dibawah UMR memiliki skor yang lebih tinggi secara signifikan pada indikator nausea and vomitting, pain, dyspnoea, constipation dan financial difficulties. Hal berbeda ditemukan oleh Ratki et al dimana dalam penelitiannya tidak didapatkan hubungan antara penghasilan individu dengan kualitas hidup pasien kanker tiroid. ${ }^{9}$ Demikian juga dalam penelitian Lee et al dimana tidak didapatkan hubungan antara penghasilan dengan kualitas hidup pasien kanker tiroid. ${ }^{14}$

Pada penelitian ini didapatkan bahwa kadar TSH tidak mempengaruhi kualitas hidup pasien kanker tiroid pada seluruh indikatornya $(\mathrm{P}>0,05)$. Hal yang sama dilaporkan dalam penelitian Lee $e t$ al dimana tidak didapatkan hubungan antara kadar TSH serum dengan kualitas hidup pasien kanker tiroid baik dalam analisis sebagai variabel kontinyu maupun sebagai variabel katagori. ${ }^{14}$ EustatiaRutten et al dalam penelitian yang melibatkan sejumlah pasien DTC $(n=24)$ yang sembuh dengan hipertiroidism subklinis selama lebih dari 10 tahun menujukkan tidak didapatkan perubahan kualitas hidup yang signifikan $(\mathrm{P}>0,05) \cdot{ }^{17} \mathrm{Hal}$ yang sama dilaporkan oleh Giusti et al dalam penelitian yang melibatkan 61 pasien DTC dibandingkan dengan pasien multinodular goiter non toksik yang sedang menjalani pengobatan T4, didapatkan penurunan kualitas hidup pada pasien DTC yang tidak berhubungan dengan kadar TSH serum. ${ }^{18}$

Pada penelitian ini didapatkan bahwa interval 
waktu sejak diagnosis hanya mempengaruhi 1 dari 15 indikator kualitas hidup pasien kanker tiroid. Hasil ini didukung oleh penelitian Almeida et al bahwa interval waktu sejak pengobatan tidak berhubungan dengan nilai kualitas hidup yang menurun pada pasien kanker tiroid. ${ }^{15}$ Gamper et al dalam penelitiannya yang menggunakan instrument EORTC QLQ-30 melaporkan bahwa terdapat peningkatan kualitas hidup pada beberapa domain setelah 12 bulan. ${ }^{19}$ Hal yang sama juga dilaporkan oleh Crevenna et al bahwa didapatkan perbaikan kualitas hidup yang signifikan pada pasien kanker tiroid setelah 1 tahun sejak diagnosis. ${ }^{13}$

Selain itu, berdasarkan jenis histopatologi tidak ditemukan mempengaruhi kualitas hidup pasien kanker tiroid pada seluruh indikatornya. Hal ini didukung oleh Gamper et al dalam penelitiannya melaporkan bahwa tipe histopatologi tidak mempengaruhi kualitas hidup pada pasien kanker tiroid. ${ }^{19}$

\section{KESIMPULAN}

Penelitian ini membuktikan bahwa kualitas hidup pasien kanker tiroid berdifferensiasi baik (DTC) paska tiroidektomi total lebih rendah dibandingkan dengan populasi umum. Faktor usia, tingkat pendidikan dan penghasilan keluarga memberikan pengaruh kuat sedangkan jenis kelamin, status pernikahan, status pekerjaan, dan interval waktu sejak diagnosis memberikan pengaruh ringan pada kualitas hidup pasien kanker tiroid berdifferensiasi baik (DTC) paska tiroidektomi total. Faktor kadar TSH dan jenis histopatologi tidak terbukti mempengaruhi kualitas hidup pasien kanker tiroid berdifferensiasi baik (DTC) paska tiroidektomi total.

\section{PERSETUJUAN ETIK}

Penelitian ini telah memperoleh persetujuan etik oleh komisi etik Fakultas Kedokteran Universitas Udayana, RSUP Sanglah, Denpasar sebelum studi dilakukan

\section{KONFLIK KEPENTINGAN}

Penulis menyatakan bahwa tidak terdapat konflik kepentingan berhubungan dengan studi.

\section{PENDANAAN}

Penulis bertanggung jawab terhadap pembiayaan studi tanpa mendapat sponsor dari pihak manapun

\section{KONTRIBUSI PENULIS}

Seluruh penulis berperan dan memiliki kontribusi terhadap penulisan laporan hasil studi meliputi analisis statistik, persiapan naskah, sintesis, maupun penyusunan draft penulisan.

\section{DAFTAR PUSTAKA}

1. Pellegriti G, Frasca F, Regalbuto C, Squatrito S, Vigneri R. Worldwide increasing incidence of thyroid cancer: update on epidemiology and risk factors. J Cancer Epidemiol. 2013; 2013:965212

2. Manuaba TW. Panduan penetalaksanaan tumor/kanker kelenjar tiroid dan paratiroid. Panduan penatalaksanaan kanker solid. Sagung seto. 2010; 53-67.

3. Dewi IGAMP; Adiputra PAT. Karakteristik Penderita Kanker Tiroid Di Bagian Bedah Onkologi RSUP Sanglah Denpasar Tahun 2009-2012. E-Jurnal Medika Udayana. 2015; 4(3):1-9

4. Gimm O, Dralle H. Differentiated thyroid carcinoma. In: Holzheimer RG, Mannick JA, editors. Surgical Treatment: Evidence-Based and Problem-Oriented. Munich: Zuckschwerdt; 2001. Available from: https://www.ncbi. nlm.nih.gov/books/NBK6979/

5. Schneider DF, Sippel RS. Measuring quality in thyroid cancer surgery. Advances in Endocrinology. 2014; Article ID 714291

6. Boger MS, Perrier ND. Advantages and disadvantages of surgical therapy and optimal extent of thyroidectomy for the treatment of hyperthyroidism. Surg Clin North Am. 2004; 84(3):849-74.

7. Husson O, Haak HR, Buffart LM, Nieuwlaat WA, Oranje WA, Mols F et al. Health-related quality of life and disease specific symptoms in long-term thyroid cancer survivors: a study from the population-based PROFILES registry. Acta Oncol. 2013; 52(2):249-58

8. Rubic $\mathrm{M}^{1}$, Kuna SK, Tesic V, Samardzic T, Despot M, Huic D. The most common factors influencing on quality of life of thyroid cancer patients after thyroid hormone withdrawal. Psychiatr Danub. 2014;26 Suppl 3:520-7.

9. Ratki SKR, Fallahi B, Namiranian N, Emami-Ardekani A, Saghari M, Mirabzadeh A, et al. Factors affecting the quality of life of well-differentiated thyroid carcinoma patients: A cross-sectional study on 435 Iranian patients. Iranian Journal of Nuclear Medicine. 2016; 24(2):92-98.

10. Yoo SH, Choi-Kwon S. Changes in Quality of Life and Related Factors in Thyroid Cancer Patients with Radioactive Iodine Remnant Ablation. J Korean Acad Nurs. 2013; 43(6):801-11.

11. Singer S, Lincke T, Gamper E, Bhaskaran K, Schreiber S, Hinz A, Schulte T. Quality of life in patients with thyroid cancer compared with the general population. Thyroid. 2012; 22(2):117-24

12. Roberts KJ, Lepore SJ, Urken ML. Quality of life after thyroid cancer: an assessment of patient needs and preferences for information and support. J Cancer Educ. 2008; 23(3):18691

13. Crevenna $\mathrm{R}^{1}$, Zettinig G, Keilani M, Posch M, Schmidinger M, Pirich $\mathrm{C}$ et al. Quality of life in patients with nonmetastatic differentiated thyroid cancer under thyroxine supplementation therapy. Support Care Cancer. 2003; 11(9):597-603

14. Lee $\mathrm{JI}^{1}$, Kim SH, Tan AH, Kim HK, Jang HW, Hur KY et al. Decreased health-related quality of life in disease-free survivors of differentiated thyroid cancer in Korea. Health Qual Life Outcomes. 2010; 8:101

15. Almeida JP ${ }^{1}$, Vartanian JG, Kowalski LP. Clinical predictors of quality of life in patients with initial differentiated thyroid cancers. Arch Otolaryngol Head Neck Surg. 2009; 135(4):342-6. 
16. Aschebrook-Kilfoy B, James B, Nagar S, Kaplan S, Seng V, Ahsan H. Risk factors for decreased quality of life in thyroid cancer survivors: initial findings from the North American Thyroid Cancer Survivorship Study. Thyroid. 2015; 25(12):1313-21

17. Eustatia-Rutten CF, Corssmit EP, Pereira AM, Frölich M, Bax JJ, Romijn JA, Smit JW. Quality of life in longterm exogenous subclinical hyperthyroidism and the effects of restoration of euthyroidism, a randomized controlled trial. Clin Endocrinol (Oxf). 2006; 64(3):284-91.

18. Giusti M, Sibilla F, Cappi C, Dellepiane M, Tombesi F, Ceresola E. A case-controlled study on the quality of life in a cohort of patients with history of differentiated thyroid carcinoma. J Endocrinol Invest. 2005; 28(7):599-608
19. Gamper EM, Wintner LM, Rodrigues M, Buxbaum S, Nilica B, Singer S. Persistent quality of life impairments in differentiated thyroid cancer patients: results from a monitoring programme. Eur J Nucl Med Mol Imaging. 2015; 42(8):1179-88

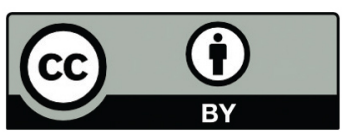

This work is licensed under a Creative Commons Attribution 